\title{
Identification of crucial message for nutrition education for school children
}

\author{
SHIKHA CHOUDHARY, SUSHMA KAUSHIK AND ELLA RANI* \\ Department of Extension Education and Communication Management, C.C.S. Haryana Agricultural \\ University, HISAR (HARYANA) INDIA
}

\begin{abstract}
Nutrition education of the school child is of paramount importance as the healthy children are supreme wealth of the nation because the foundation for life time, health, strength and intellectual vitality is laid during this period. Maintaining a balanced diet and regular exercise is important for all individuals, especially school-aged children (6-12 years). These children are required to eat a variety of foods from each food group to ensure optimal intake of all vitamins, proteins and minerals. At the same time, they may face new challenges regarding food choices and habits. So, decisions about what to eat are partly determined by what is provided in school, at home, the influences from friends at school, and the media, especially television. For taking these points in mind, different crucial message were identified for nutrition education for school children. Hence, study was conducted in Hisar district of Haryana State. The results showed that from the list of fourteen main messages and thirty seven sub-messages three main messages viz., balance diet, protective foods and food hygiene were identified with its thirteen sub-messages viz., 'importance of balanced diet', 'functions of balanced diet', 'food group' and 'nutritional requirement of school children'.
\end{abstract}

KeY Words : Nutrition education, School children, Food consumption

View Point Article : Choudhary, Shikha, Kaushik, Sushma and Rani, Ella (2015). Identification of crucial message for nutrition education for school children. Internat. J. Home Sci. Extn. \& Comm. Manage., 2 (1): 28-32.

Article History : Received : 01.10.2014; Revised : 25.11.2014; Accepted : 11.12 .2014

* Author for correspondence : (Email : raniella9@ gmail.com) 